\author{
Yu. Andrienko 1, *, G. Milinevsky 1, 2, 3, V. Danylevsky ${ }^{1}$ \\ ${ }^{1}$ Taras Shevchenko National University of Kyiv, Kyiv, 01601, Ukraine \\ ${ }^{2}$ State Institution National Antarctic Scientific Center, Ministry of Education \\ and Science of Ukraine, Kyiv, 01601, Ukraine \\ ${ }^{3}$ International Center of Future Science, College of Physics, Jilin University, \\ Changchun, 130012, China \\ *Corresponding author: andrienko.j@gmail.com
}

\title{
Vertical ozone profiles in the atmosphere over the Antarctic Peninsula and Kyiv by Umkehr observations
}

\begin{abstract}
The Umkehr observations over Kyiv (Ukraine) and Antarctic Peninsula areas were processed for the first time to retrieve and analyse the vertical distribution of ozone. The Umkehr observations have been pre-processed using the UMK92 software package proposed by the World Ozone and UV-radiation Data Centre (WOUDC). The set of the calculated vertical ozone profiles for Kyiv-Goloseyev station (2011-2020) and Akademik Vernadsky station (2005-2009) has been obtained. Analysis of ozone profiles observed with Dobson spectrophotometer D040 indicates that the maximum ozone concentration is located in the altitude range of $15-25 \mathrm{~km}$ with an average height of $19.8 \pm 1.4 \mathrm{~km}$. It corresponds to the layer of maximum ozone concentration in the mid-latitude stratosphere. The maximum ozone partial content in Dobson Units per the layers (DU/layer) with thickness of $5 \mathrm{~km}$ altitude for most of the years are of 60-80 DU/layer. There are also days with the maximum ozone content significantly larger than an average. A characteristic feature of the profiles is that the lower ozone content occur in summer and autumn months in the range of 60-75 DU/layer. The winter and spring profiles demonstrate higher ozone values at the maximum. To analyse the vertical profiles of ozone in Antarctic Peninsula area, we use Umkehr data from observations at the Akademik Vernadsky station with the Dobson D123 spectrophotometers in 2005-2009. The data processing and the calculation of the vertical ozone profiles was provided according to the methodology developed at the Kyiv-Goloseyev station. It is shown that the ozone profiles at the Akademik Vernadsky station vary in a wide range of values of the maximum ozone concentration from 40 to $110 \mathrm{DU} /$ layer. Ozone content at maximum of vertical distribution was changing dramatically from day to day in the Antarctic region during the ozone hole period.
\end{abstract}

Keywords: climate, Dobson spectrophotometer, ozone hole, seasonal variation, stratosphere, total ozone content

\section{Introduction}

Atmospheric ozone concentrations are affected by various parameters, including dynamic variability (Fusco \& Salby, 1999) and climate change (Rex et al., 2004). Changes in stratospheric ozone can be used to climate numerical prediction, to check internal heat- ing and energy balance in the stratosphere (Gettelman et al., 2011). Since the 1920s, systematic total ozone observations using direct solar radiation and radiation from the sky at the zenith have been introduced by Dobson and Harrison (1926). Since 1984, similar measurements have been made with the Brewer spectrophotometer (WMO, 1998), when the evi- 
dence of stratospheric ozone decline became obvious (Staehelin et al., 1998a; 1998b). The problem with stratospheric ozone layer is considered in Intergovernmental Panel on Climate Change (IPCC) scientific report 2013 in connection with Montreal Protocol (Hartmann et al., 2013). Stratospheric ozone decline was observed until mid-1990s when it reached $3.5 \%$ lower pre-1980s level. Ozone content trend in the Earth atmosphere are the basis for revising the Radiative Forcing from $-0.05 \pm 0.10 \mathrm{~W} \mathrm{~m}^{-2}$ in 1750 to $-0.10 \pm 0.15 \mathrm{~W} \mathrm{~m}^{-2}$ in 2005 (Myhre et al., 2013). These values strongly depend on the vertical distribution of the stratospheric ozone changes because of tropospheric ozone accounts for only about $10 \%$ of the total ozone column (TOC) (Hartmann et al., 2013; Hassler et al., 2014). Two altitude regions are mainly responsible for long-term changes in the TOC. In the upper stratosphere ( 35 to $45 \mathrm{~km}$ ), there was a strong and statistically significant decline (about 10\%) up to the mid-1990s and little change since then. In the lower stratosphere, between 20 and $25 \mathrm{~km}$ over midlatitudes, ozone also experienced a statistically significant decline ( 7 to $8 \%$ ) between 1979 and the mid1990s, followed by stabilization or a slight (2 to 3\%) increase (Hartmann et al., 2013). Minimum of the TOC corresponded to the peak of the equivalent effective stratospheric chlorine (EESC) maximum that occurred in the second half of the 1990s.

Due to the ozone decline is different at different altitudes, the vertical ozone content study is extremely important to reveal the ozone trend (Harris et al., 2015). Results of new analysis of the ozone trends were published in the most recent report of the WMO (WMO, 2018). Observations indicated that there was no statistically significant trend in near-global $\left(60^{\circ} \mathrm{S}-\right.$ $\left.60^{\circ} \mathrm{N}\right)$ TOC over the $1997-2016$ period. New datasets were obtained and focused studies ozone profile changes were performed recently. Ball et al. (2019) has recently suggested that ozone in the lower stratosphere $(<24 \mathrm{~km})$ continued to decline over the 1998 2016 period and tropical stratospheric ozone column $\left(1-100 \mathrm{hPa}, 30^{\circ} \mathrm{S}-30^{\circ} \mathrm{N}\right)$ decreases significantly (Ball et al., 2019).

Ozone profile trends over the period 2000 to 2016 are discussed in Steinbrecht et al. (2017). The data indi- cate significant ozone changes between 35 and $48 \mathrm{~km}$ altitude. Below $35 \mathrm{~km}$, in 2000-2016 period ozone trends are not statistically significant. The observed trends are consistent with expectations from chemistry climate model simulations. Almost all data sets indicate ozone increase in the upper stratosphere. Uncertainties have been reduced for the trend near $2 \mathrm{hPa}$ in the 35 to $60^{\circ}$ latitude bands from about $\pm 5 \%$

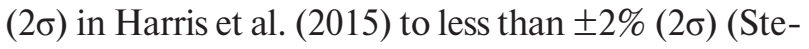
inbrecht et al., 2017).

These uncertainties are critical to provide altitude ozone distribution study. For these purposes, the Umkehr method was first introduced in the 1930s to measure the vertical ozone profiles in the atmosphere (Götz et al., 1934). The first numerical Umkehr model was developed by Dütsch (1959) with later improvements by Mateer and Dütsch (1964). This method has been applied as the base to all Umkehr observations from the world network at the World Ozone Data Center (WOUDC) after introduction of new ozone absorption coefficients (Bass \& Paur, 1985) in UMK92 algorithm (Mateer \& Deluisi, 1992) and later UMK04 algorithm presented by Petropavlovskikh et al. (2005). To date, Umkehr method developments are underway to improve the algorithm for reproducing the vertical distribution of ozone (Petropavlovskikh et al., 2005; Stone, 2015) and comparing the results with satellite observations (Laeng et al., 2014; Bernhard et al., 2017).

Ozone observations with a Dobson spectrophotometer (STN232, FAD) at British Antarctic Survey base Faraday started in 1956. Later, in 1996 the Faraday base has been transferred to Ukraine. The base was renamed Akademik Vernadsky (hereinafter Vernadsky) station. Ozone measurements with Dobson spectrophotometer D031 at the FAD station were continued by Ukrainian scientists. Dobson spectrophotometer D031 has been replaced by Dobson D123 in March 2005. The stratospheric ozone observations with Dobson spectrophotometer at the KyivGoloseyev station (STN498, KGV) started in 2010. These observations provide TOC values and the Umkehr altitude ozone distribution data. Umkehr observations were used to retrieve and analyse the vertical profiles of ozone over Kyiv and Antarctic Peninsula areas. 
The main goal of this study is retrieve the Umkehr vertical ozone profiles variability over the KGV Dobson station (Ukraine) and over Vernadsky FAD station in Antarctic Peninsula. These profiles were processed for the first time. In Section 2, the Dobson ozone observations and Umkehr data processing software are briefly described. The results of vertical ozone observations at $\mathrm{KGV}$ and FAD stations are considered in Section 3 followed by discussion and conclusions in Section 4.

\section{Data and method}

\section{Dobson ozone observations}

Observations with Dobson spectrophotometer in Ukraine started in May 2010 (Milinevsky et al., 2012) at the Kyiv-Goloseyev station, located in Kyiv, $10 \mathrm{~km}$ south of the city center. Observations are made using a Dobson D040 spectrophotometer as part of the network established by the World Meteorological Organization (WMO). Data allow determining the parameters of ozone in the Earth's atmosphere: total ozone column and vertical distribution of ozone (Umkehr method). At Faraday/Vernadsky the longest time series of the Antarctic ozone measurements is supported. These observations allow to determine the TOC in a wide range of meteorological conditions, both in clear weather using the direct Sun light (observations type Direct Sun - DS) and light scattered by the atmosphere from in cloudless zenith (Zenith Blue - ZB) conditions, and in cloudy weather (Zenith Cloud - ZC) using light scattered by the atmosphere and clouds at zenith.

In this paper we consider ozone vertical profiles obtained with the Dobson D040 spectrophotometer over Kyiv in 2011-2020 and the Dobson D123 spectrophotometer over Vernadsky in the period 2005-2009.

\section{Umkehr measurements}

In contrast to the TOC observations, only the stable clear weather is suitable for determining the vertical ozone profiles by the Umkehr method. Umkehr measurements provide data on ozone up to a height of $48 \mathrm{~km}$ and, with higher precision up to a height of $30 \mathrm{~km}$. Standard Umkehr observations consist of mea- surements of a pair of C lines $(311.45 \mathrm{~nm}, 332.4 \mathrm{~nm})$ at 14 zenith angles (Komhyr \& Evans, 2008). The Umkehr method for determining the vertical ozone distribution in the atmosphere has been first proposed by Götz et al. (1934) and is currently applied to ozone studies with Dobson spectrophotometer (Stone et al., 2015; Bahramvash Shams et al., 2019). The Umkehr technique is based on the analysis of the brightness ratio of zenith sky at a pair of ultraviolet wavelengths (Komhyr \& Evans 2008; Stone et al., 2015). The resulting ozone profile derived from reduction of these measurements is quite dependent on the used algorithm. The standard Umkehr technique uses the fact that light with a wavelength of $311.4 \mathrm{~nm}$ (intensity $I$ ) is more strongly absorbed by ozone, and light with a wavelength of $332.4 \mathrm{~nm}$ (intensity $I^{\prime}$ ) is less absorbed by ozone. It is assumed that the light comes to the spectrophotometer as a result of single scattering throughout total atmospheric column. The intensity of scattered light at any level of the atmosphere depends on the number of molecules in the atmosphere column over that level and is determined by two factors: ozone absorption and scattering by air molecules. The detailed description of the method is provided in (Mateer \& Deluisi, 1992; Stone et al., 2015). To retrieve the vertical ozone distribution, the $N$-values are used (1). The ratio of intensities $I / I^{\prime}$ is obtained from Dobson spectrophotometer observations. The actual measurement is the $R$-dial readings, which is then converted to atmospheric radiation using calibration procedures.

$$
N \text {-value }(z)=100 \log _{10}\left(I / I^{\prime}\right)+K,
$$

the value $K$ is a constant and depends on the spectrophotometer. The plot of the Umkehr dependency is shown in Figure 1.

Mateer and Dütsch (1964) developed the first computerized version of the algorithm UMK64 to restore the vertical distribution of ozone. Two decades later, new ozone absorption coefficients and a new mathematical method of calculation were published by Bass and Paur (1985). A new algorithm UMK92, which uses improved ozone absorption coefficients and their temperature dependence, was developed by Mateer and Deluisi (1992) and is currently widely used in WOUDC, 


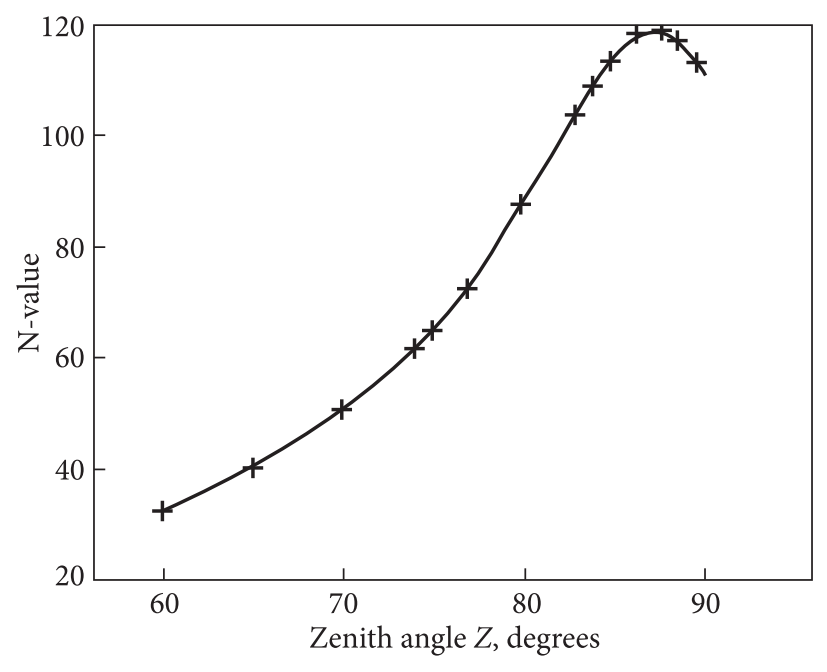

Figure 1. Umkehr N-value plot by observations on September 23, 2020 at the Kyiv-Goloseyev station

Toronto, Canada. The Umkehr observations at the KGV station (Ukraine) and over the FAD station in Antarctic Peninsula have been pre-processed using the UMK92 software package proposed by the WOUDC. For ozone profiles retrievals the advanced algorithm UMK04 has been developed (Petropavlovskikh et al., 2005). The comparison of UMK92 and UMK04 shows that the difference in errors of these two algorithms is small. We are going to recalculate $\mathrm{KGV}$ and FAD Umkehr data using UMK04 in the next study for long-term ozone profiles trend analysis.

The UMK92 algorithm basic features are following (Mateer \& Deluisi, 1992). The calculation of diffusely transmitted radiance in the zenith direction is carried out for a clear, dry, spherically homogeneous atmosphere with molecular scattering and ozone absorption. For the retrieval of the ozone vertical profile, the atmosphere is divided into 16 layers. For publication and archiving the profile is reported in 10 layers, with layer 10 including all ozone above layer 9, and layer 1 including the retrieved ozone amounts for both layers 0 and 1 . So, layers $0-1$ are extended to the altitude of the layer 2 base that is $10.3 \mathrm{~km}$. The base of layer 10 is located at altitude of $47.9 \mathrm{~km}$. The altitude resolution is quite broad, the thickness of the tropospheric layer is approximately $10 \mathrm{~km}$, and the thickness of the stratospheric layers are 4.4 to $5.3 \mathrm{~km}$.
The radiative transfer calculations utilize the ozone absorption cross-sections and their temperature dependence, and the Rayleigh scattering. The absorption coefficient temperature effect is included. An average temperature is calculated for each of the forward model layers and, from this temperature, a layer-average ozone absorption coefficient is also calculated, using the weighted coefficients. The atmospheric temperature profile used is the average profile for all months for average North and South latitude $45^{\circ}$.

Multiple scattering corrections are calculated using iteration of the auxiliary equation of radiative transfer in a pseudo-spherical atmosphere, primary scattering is calculated for a spherically homogeneous atmosphere, while higher orders of scattering are calculated for a flat atmosphere. The refraction corrections are calculated using a primary scattering model and the 1962 U.S. Standard Atmosphere geometric heights for the temperature-pressure-height relationship.

The sensitivity to stratospheric aerosol remains quite significant for the UMK92 algorithm. In UMK92 the errors are a strong function of aerosol altitude and are largest for the uppermost and lowermost layers. The conclusion of Mateer and Deluisi (1992) is only the retrievals in layers $4-8(19-43 \mathrm{~km})$ should be used in ozone trend analysis. These matters are inherent in the physics of the Umkehr method.

\section{Results}

\section{Kyiv-Goloseyev ozone profiles}

The data from Umkehr observations obtained using a Dobson spectrophotometer at the WOUDC No 498 Kyiv-Goloseyev station $(50.35 \mathrm{~N}, 30.29 \mathrm{E})$ for the 2011-2020 period (Table 1) were used for analysis.

The number of vertical ozone profiles is reasonably small because Umkehr observations require cloudless weather conditions. The vertical ozone profiles are shown in Figures 2-4. Each plot shows profiles for one year, which allows estimating changes in ozone distribution during the year. The symbols on the curves correspond to the values of the ozone content in the Umkehr layers, the lines are obtained by spline interpolation. 

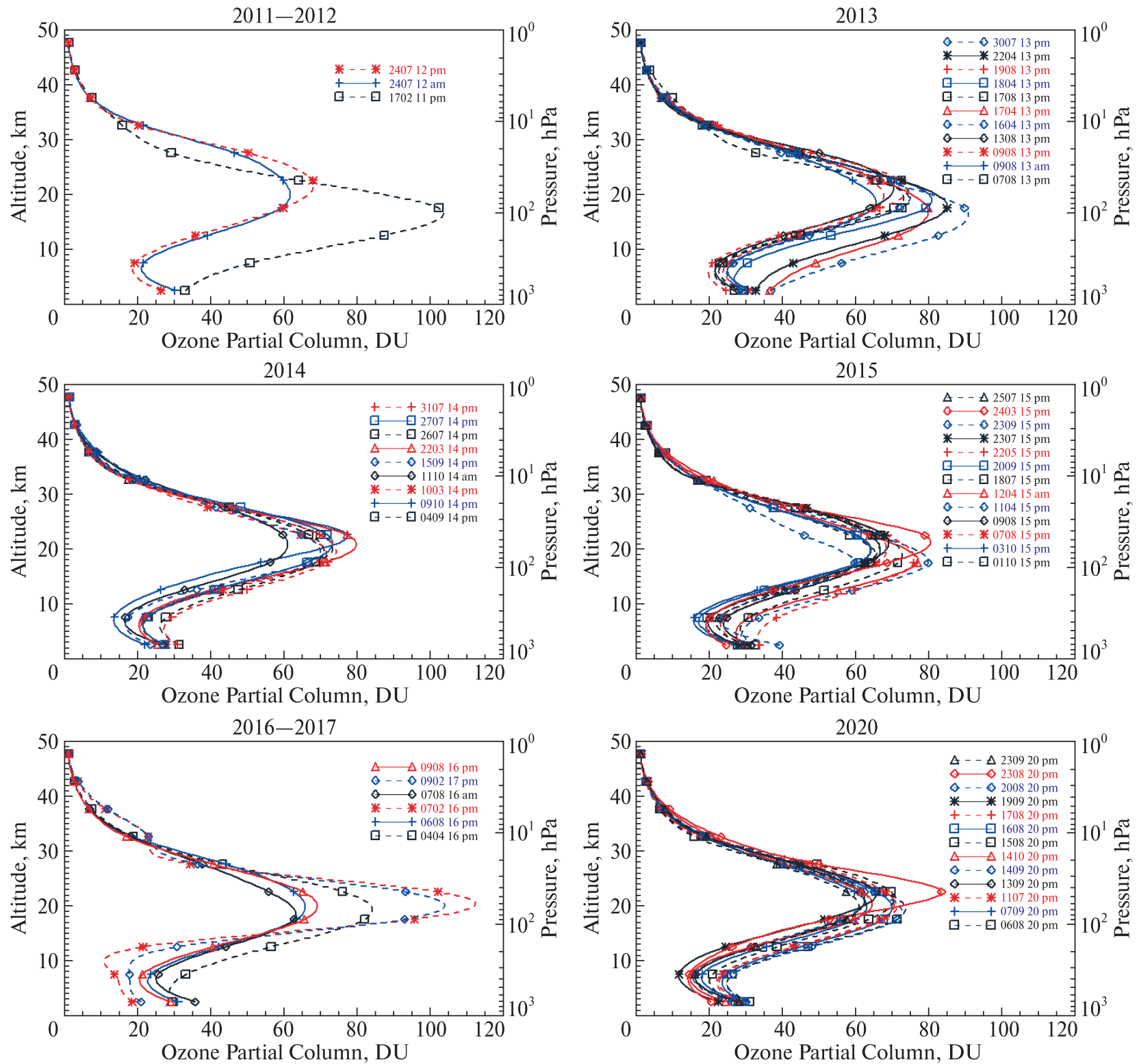

Figure 2. The vertical ozone profiles in DU/layer units and covered the 2011-2020 period. For convenience, all plots are presented in the same $\mathrm{X}$-axis scale. In the profile date am and pm indicate morning and evening Umkehr observations

Profiles are displayed in ozone partial column values (Dobson Unit per layer - DU/layer, marked as DU in the Figures), where "layer" is the corresponding altitude range for which this value is calculated. In this case, the integral value in DU for all layers on the profile is equal to TOC in DU for this day of observations. The thickness of each Umkehr layer is ap- proximately $5 \mathrm{~km}$. The ten layer values in Umkehr profiles cover the altitude range of approximately $0-50 \mathrm{~km}$ (Fig. 2).

In Figure 2, all profiles show a fairly similar altitude distribution and for most years are close with small differences in values. The maximum concentration in the stratosphere is within the altitudes of 

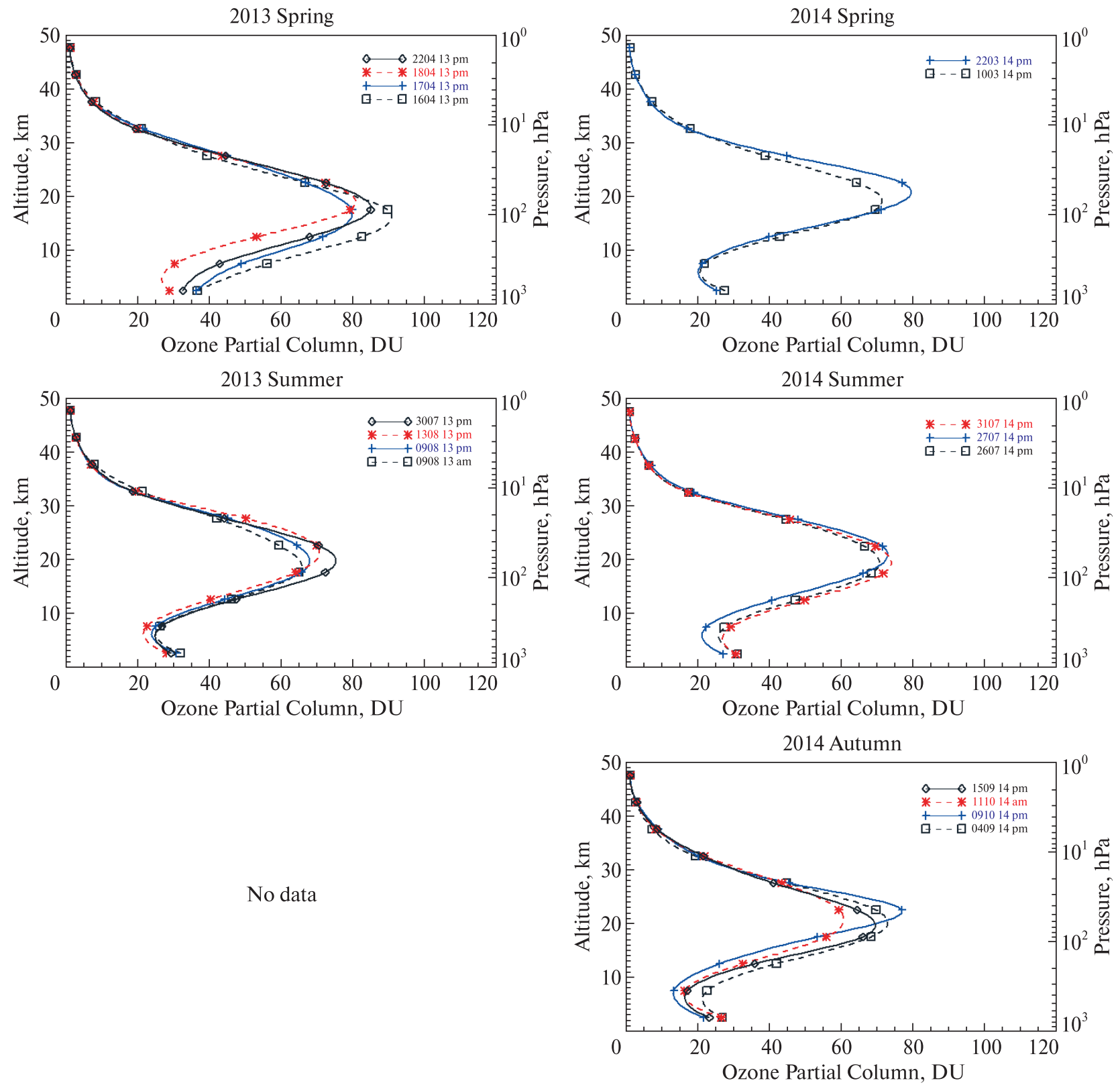

Figure 3. Vertical ozone distribution over Kyiv area in 2013, 2014. Profiles are presented in DU/layer values depending on the season

Table 1. The number of profiles of the vertical ozone distribution analyzed according to the Kyiv-Goloseyev station data over the years. Total number is 53

\begin{tabular}{|c|c|c|c|c|c|c|c|c|}
\hline Year & 2011 & 2012 & 2013 & 2014 & 2015 & 2016 & 2017 & 2020 \\
\hline Number of profiles & 1 & 2 & 9 & 9 & 13 & 5 & 1 & 13 \\
\hline
\end{tabular}


15-25 km, which corresponds to the lower stratosphere. The maximum ozone values for most years are in the range of 60-80 DU/layer.

However, some profiles exhibit significant differences as a higher maximum value of ozone compared to neighbouring dates. Thus in 2016 , for the profile on February 7 the maximum ozone value was almost
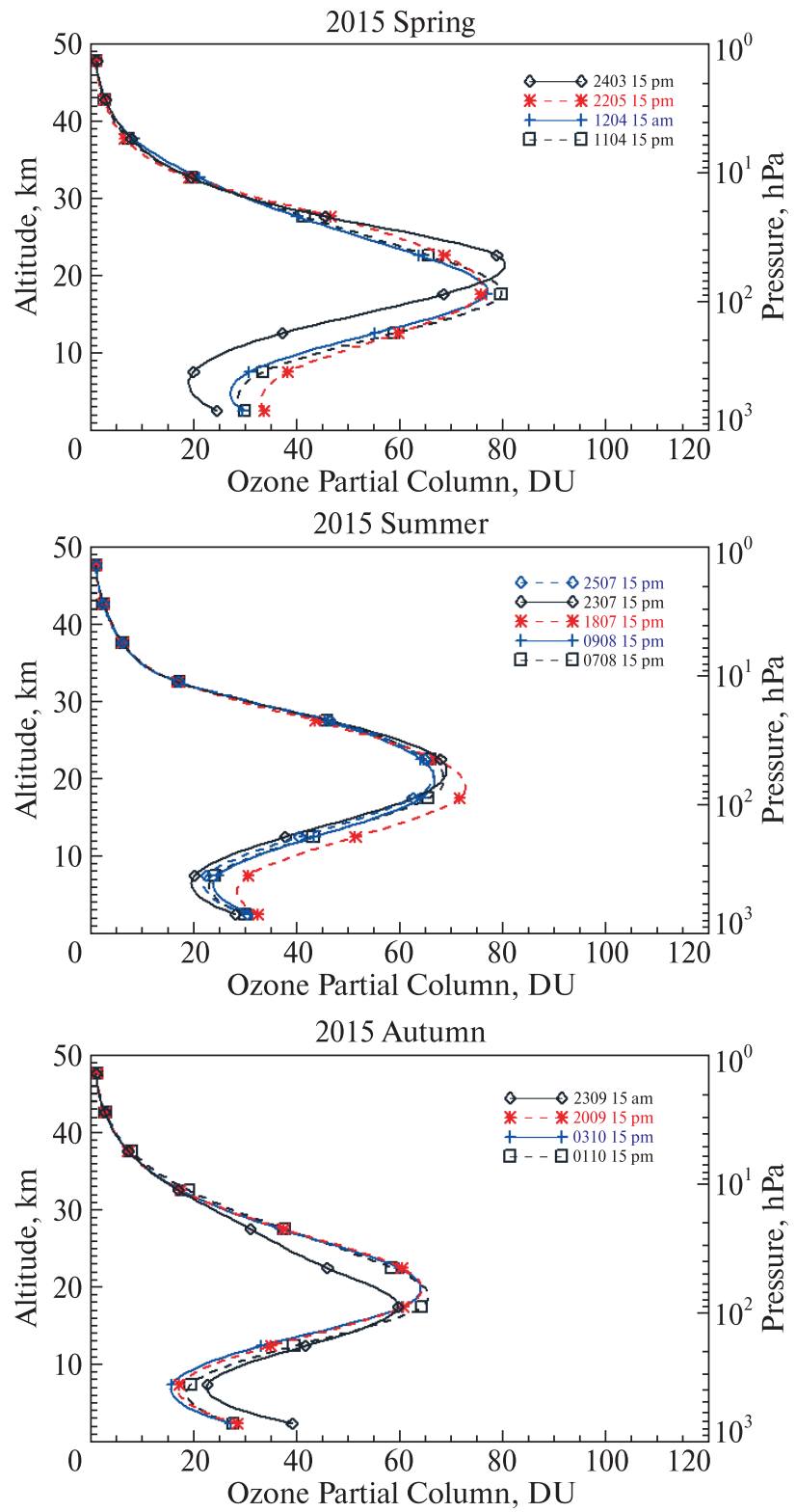

30 DU larger than for the nearest observed date of April 4. A similar discrepancy is observed in 2020 for the August 23 profile. The profiles for February 02, 2011 and February 09, 2017 are difficult to compare due to the lack of other measurements in these years.

For more detailed analysis, we consider seasonal changes in ozone altitude distribution (Figs. 3, 4).

No data
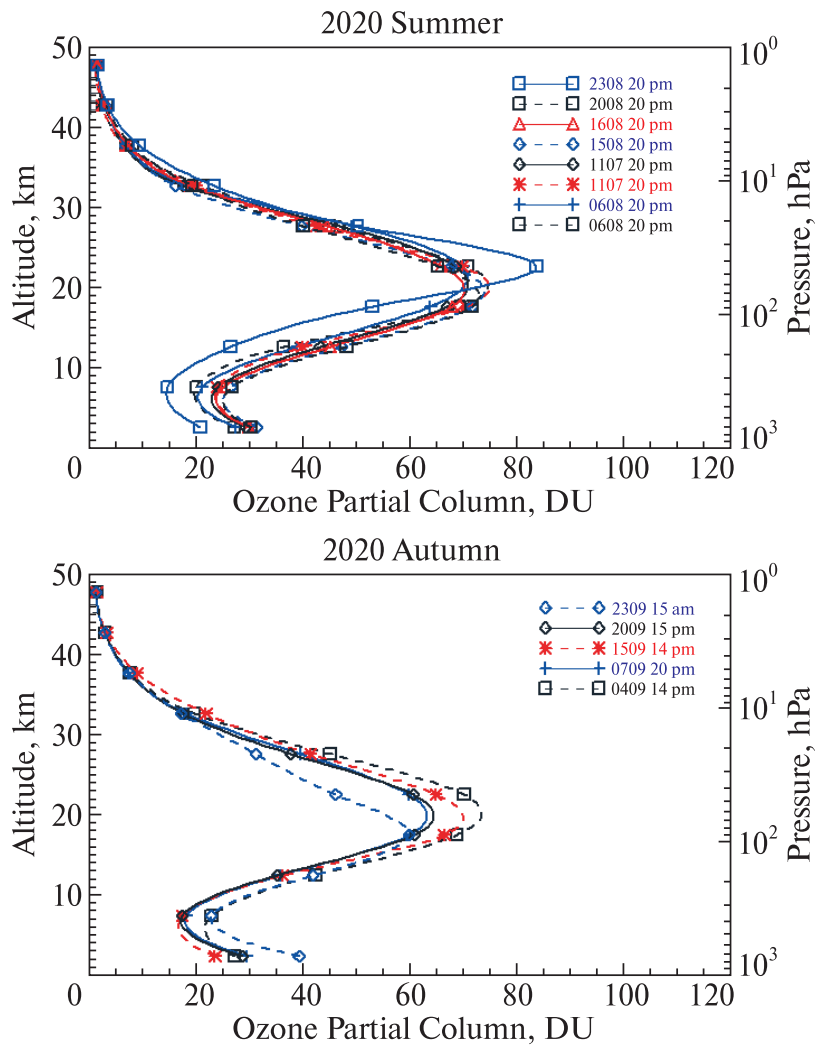

Figure 4. Vertical ozone distribution over Kyiv area in 2015, 2020. Profiles are presented in DU/layer values depending on the season 

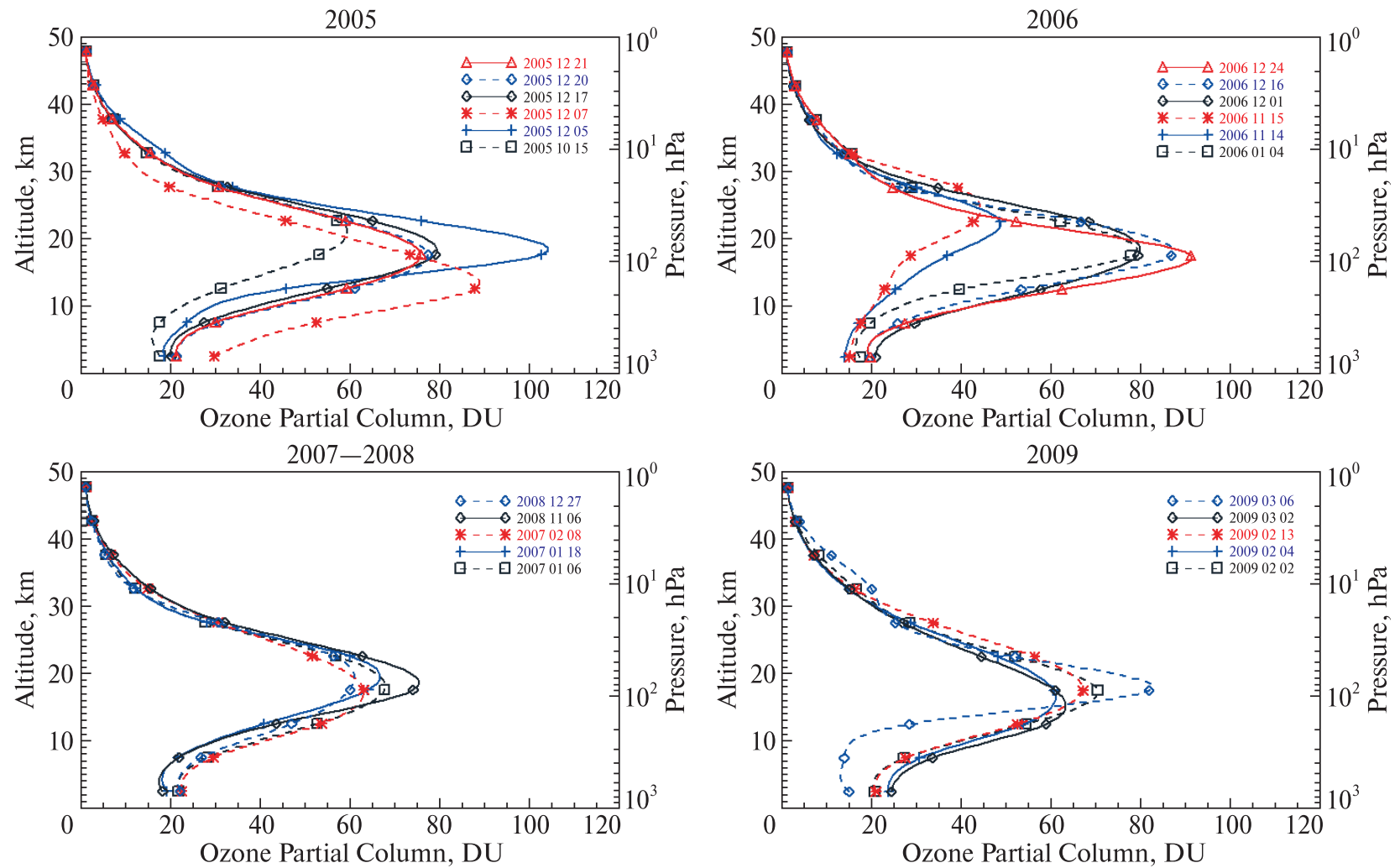

Figure 5. Vertical ozone distribution over Vernadsky station by the Dobson D123 spectrophotometer, WOUDC station 232 FAD. Data are collected in the period from 2005 to 2009

For summer profiles the maximum ozone partial column value is in the range of $65-75 \mathrm{DU} /$ layer for all observations. This is well seen in the August 2020 ozone profiles. In general, during the summer observation period on eight ozone profiles the ozone distribution is similar with the maximum ozone value is $70-75 \mathrm{DU} /$ layer. The exception is the August 23, 2020 profile which is very different from others and exhibits the maximum ozone partial column value $\sim 83$ DU/layer, while the

Table 2. The number of profiles of the vertical ozone distribution analyzed according to the Vernadsky station data over the 2005-2009 period.

Total number is 22

\begin{tabular}{|c|c|c|c|c|c|}
\hline Year & 2005 & 2006 & 2007 & 2008 & 2009 \\
\hline $\begin{array}{c}\text { Number } \\
\text { of profiles }\end{array}$ & 6 & 6 & 3 & 2 & 5 \\
\hline
\end{tabular}

closest observations from August 20 have a profile with maximum ozone of $\sim 65 \mathrm{DU} /$ layer.

For autumn profiles, the characteristic maximum ozone value is seasonally lowest in the range of $60-70$ DU/layer. In October 2014 we provided observations with a time difference of two days and a discrepancy in maximum values is about $20 \mathrm{DU} /$ layer (October 9, maximum ozone is of 77 DU/layer; in October 11, maximum ozone is of 59.5 DU/layer).

Winter profiles are sparse due to usually cloudy weather and presented by data for February 2016 and February 2017 (Fig. 4 top right panel). The value of the winter maximum in the profile for February 7 , 2016 is of 102 DU/layer, on February 2, 2017 - 93 DU/layer. When comparing the winter (February 7 102.1 DU/layer) and summer (August 9 - 65.6 DU/ layer) profiles in 2016, the difference between the maximum values is of $37 \mathrm{DU} /$ layer. That confirms the annual variations of total ozone with maximum in 

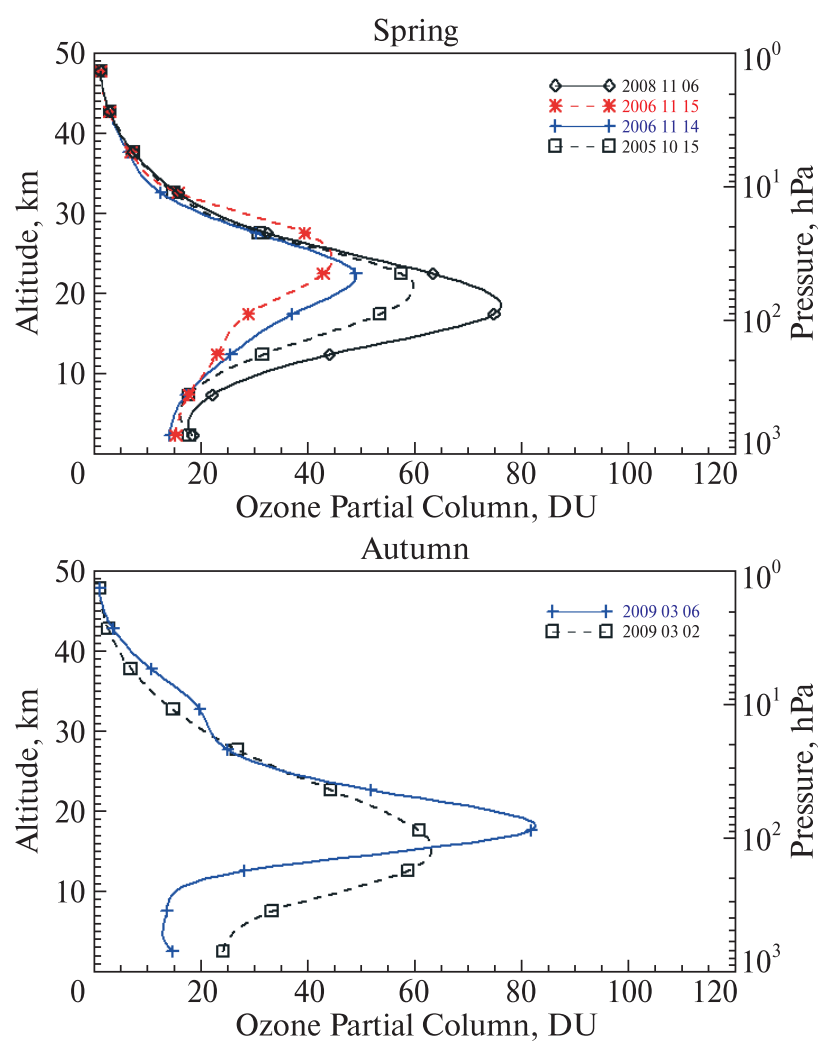

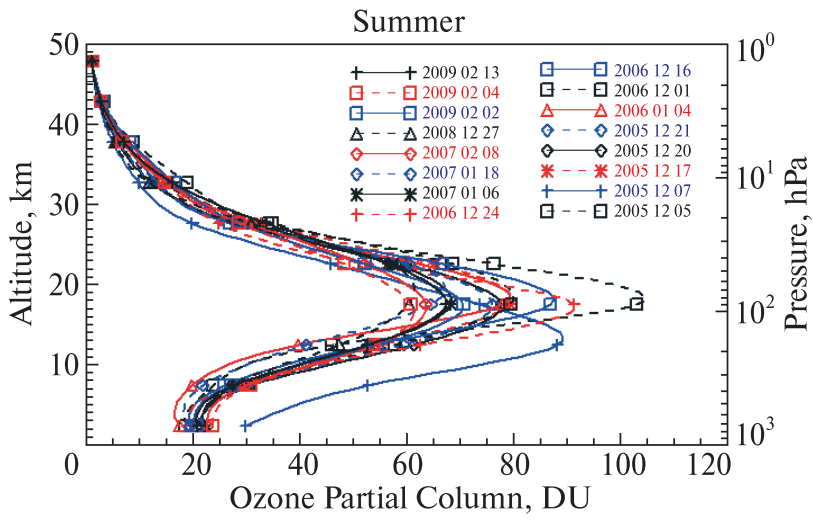

No data in the Southern Hemisphere winter period

Figure 6. Distribution of ozone with altitude for the three Antarctic seasons in Southern Hemisphere over Vernadsky station, observations in the 2005-2009 period

winter and spring and minimum in autumn (Hood \& Zaff, 1995; Evtushevsky et al., 2014).

\section{Vernadsky ozone profiles}

The stratospheric ozone observations with Dobson spectrophotometer D123 at the Vernadsky station were used to retrieve and analyse the vertical distribution of ozone over Antarctic Peninsula area. Using the same procedure as for the Kyiv-Goloseyev station data, we calculated the vertical ozone distributions for the 2005-2009 period (Table 2).

Figure 5 presents the annual set of the ozone vertical distribution profiles at the period 2005-2009. The graphs show that the profiles differ in a wide range of values of the maximum ozone concentration from 40 to $110 \mathrm{DU} /$ layer. The maximum of ozone is in the range of altitudes from $13 \mathrm{~km}$ (December 07, 2005) to $25 \mathrm{~km}$ (November 15, 2006).
The 2005 profiles (Fig. 5) are presented from October 15 to December 21 . The ozone maximum value changes and variations of the maximum position are seen. In December 5, the maximum ozone value is of $\sim 103 \mathrm{DU} /$ layer corresponds to an altitude of $18 \mathrm{~km}$, but in December 7 , the maximum value is of $\sim 88$ DU/layer corresponds to an altitude of $\sim 13 \mathrm{~km}$.

The 2006 profiles (Fig. 5) are presented from January 4 to December 24. In January 4, the maximum ozone value is of $78 \mathrm{DU} /$ layer, in November 14, 15-48.6 DU/layer and 42.6 DU/layer, respectively, while in December 24, the ozone value at the maximum is of $91 \mathrm{DU} /$ layer. That is evidence of ozone concentrations decrease two-fold in one month and recovering to the previous value also during one month. This variations should be considered taking into account the position and dynamics of ozone hole over the FAD station, that is located at the ozone hole edge. 
Figure 6 shows the vertical distributions of ozone for the period under study for different Antarctic seasons. For summer profiles (Fig. 6, summer) the most characteristic values of the maximum ozone concentration are the range of values 60-90 DU/layer, which corresponds to an altitude of about $18 \mathrm{~km}$. Small additional maxima are observed at the altitude of about $33 \mathrm{~km}$ on the profiles constructed by the data at the end of February and at the beginning of March (Fig. 6, autumn). Profiles constructed for the spring season are presented in November data for the discussed years (Fig. 6, spring) and show a wide range of changes in the maximum ozone concentration in this period from year to year.

The profiles obtained at the Vernadsky station show that the seasonal ozone values at the maximum ozone concentration have a wider range of values. Similar to the Kyiv-Goloseyev data, the profiles with a lower maximum ozone concentration value have a maximum at high altitudes. For example, the maximum value of ozone concentration is 45 DU/layer at altitude of $24 \mathrm{~km}$ (on November 15, 2006), and 83 DU/layer at altitude of $19 \mathrm{~km}$ (on March 06, 2009).

\section{Discussion and conclusions}

The first results of processing the Umkehr observations over Kyiv (Ukraine) and Vernadsky (Antarctic Peninsula) stations were provided to retrieve the vertical distributions of ozone and to analyse their seasonal variations. To data processing the software package was developed, which in conjunction with the WOUDC program UMK92 allows to retrieve the vertical distribution of ozone using Umkehr observations.

The data of Umkehr observations at Kyiv-Goloseyev station for the period 2011-2020 were processed. The obtained ozone distributions show that in the mentioned period gradual increasing of TOC was registered over the Kyiv-Goloseyev station. The value of ozone partial column at the altitude highest concentration (about $20 \mathrm{~km}$ ) during the year varies in 60-110 DU/ layer. Winter and spring ozone concentrations at altitudes above $15 \mathrm{~km}$ exceed the values observed in other seasons. These seasons are characterized by ozone par- tial column values in the range of 75-85 DU/layer, for some observations 100-110 DU/layer. The spring concentration of ozone at the maximum of its profile tends to exceed the summer one. The summer months are characterized by the values of the maximum concentration in the range of 65-75 DU/layer. In autumn the minimum ozone partial column value about $60 \mathrm{DU} /$ layer is observed at the heights of the maximum. These seasonal variations in ozone can be explained by the Brewer-Dobson circulation, when reach ozone air enters to the stratosphere at the equator and moves in the stratosphere to the mid-latitude and polar latitudes, and descends into the troposphere. Brewer-Dobson circulation is stronger in the winter hemisphere than in the summer (Brewer, 1949; Hardiman et al., 2017).

The profiles obtained at the Vernadsky station show that the seasonal ozone partial column values at the maximum ozone concentration have a wider range of variations. For example in 2006, the ozone content in the profile maximum decreases two-fold in one month and recovers to the previous value also during one month. This variations should be considered taking into account the position and dynamics of ozone hole over the Vernadsky station, located at the ozone hole edge. Similar to the Kyiv-Goloseyev data, the profiles with a lower maximum ozone concentration exhibit the maximum at highest altitudes. The detailed analysis of vertical ozone profiles from Umkehr observation over Kyiv-Goloseyev and Vernadsky stations will be provided in future work. The comparison of satellite ozone profiles with Umkehr retrievals will also be undertaken. The Umkehr profiles processed for Faraday/Vernadsky data from 1971-2020 period will allow to retrieve the comprehensive seasonal and interannual ozone altitude profile variations, which are most sharp during ozone hole period.

Author contributions: conceptualization, G.M.; methodology, Yu.A. and G.M.; software, Yu.A. and G.M.; validation, G.M. and V.D.; investigation, G.M., Yu.A. and V.D.; observations G.M. and V.D.; writing original draft preparation, Yu.A. and G.M.; writing review and editing, Yu.A., V.D. and G.M. Each author contributed to the analysis and discussion of the results and edited the manuscript. 
Acknowledgments: This work was partly supported by the Ministry of Education and Science of Ukraine through the projects 19BF051-08 and 20BF051-02 of the Taras Shevchenko National University of Kyiv. This work also contributed to the State Institution National Antarctic Scientific Center of the Ministry of Education and Science of Ukraine research objectives. The authors would also like to thank observers from the Dobson Kyiv-Goloseyev and Vernadsky stations who provided valuable Umkehr observations.

Funding: This research received no external funding.

Conflict of Interest: The authors declare no conflict of interest.

\section{References}

Bahramvash Shams, S., Walden, V. P., Petropavlovskikh, I., Tarasick, D., Kivi, R., Oltmans, S., Johnson, B., Cullis, P., Sterling, C. W., Thölix, L., \& Errera, Q. (2019). Variations in the vertical profile of ozone at four high-latitude Arctic sites from 2005 to 2017. Atmospheric Chemistry and Physics, 19, 9733-9751. https://doi.org/10.5194/acp-19-9733-2019

Ball, W. T., Alsing, J., Staehelin, J., Davis, M. S., Froidevaux, L., \& Peter, T. (2019). Stratospheric ozone trends for 1985-2018: sensitivity to recent large variability. Atmospheric Chemistry and Physics, 19, 12731-12748. https://doi.org/10. 5194/acp-19-12731-2019

Bass, A. M., \& Paur, R. J. (1985). The ultraviolet crosssection of ozone: I. The measurements. In C. S. Zerefos, A. Ghazi (Eds.), Atmospheric Ozone (pp. 606-610). Springer, Dordrecht. https://doi.org/10.1007/978-94-009-5313-0_120

Bernhard, G., Petropavlovskikh, I., \& Mayer, B. (2017). Retrieving vertical ozone profiles from measurements of global spectral irradiance. Atmospheric Measurement Techniques, 10, 4979-4994. https://doi.org/10.5194/amt-10-4979-2017

Brewer, A. W. (1949). Evidence for a world circulation provided by the measurements of helium and water vapour distribution in the stratosphere. Quarterly Journal of the Royal Meteorological Society, 75(326), 351-363.https://doi.org/10.1002/ qj.49707532603

Dobson, G. M. B., \& Harrison, D. N. (1926). Measurements of the amount of ozone in the Earth's atmosphere and its relation to other geophysical conditions. Proceedings of the Royal Society of London A, 110, 660-693. https://doi.org/10.1098/ rspa. 1926.0040

Dütsch, H. U. (1959). Vertical ozone distribution from Umkehr observations. Archiv für Meteorologie, Geophysik und Bioklimatologie, Serie A, 11, 240-251.

Evtushevsky, O., Grytsai, A., \& Milinevsky, G. (2014). On the regional distinctions in annual cycle of total ozone in the northern midlatitudes. Remote Sensing Letters, 5(3), 205-212. http://dx.doi.org/10.1080/2150704X.2014.894653

Fusco, A. C., \& Salby, M. L. (1999). Interannual variations of total ozone and their relationship to variations of planetary wave activity. Journal of Climate, 12(6), 1619-1629. https://doi. org/10.1175/1520-0442(1999)012<1619:ivotoa >2.0.co;2

Gettelman, A., Hoor, P., Pan, L. L., Randel, W. J., Hegglin, M. I., \& Birner, T. (2011). The extratropical upper troposphere and lower stratosphere. Reviews of Geophysics, 49(3). https://doi:10.1029/2011RG000355

Götz, F. W. P., Meetham, A. R., \& Dobson, G. M. B. (1934). The vertical distribution of ozone in the atmosphere. Proceedings of the Royal Society of London. Seria-A, 145, 416446. https://doi.org/10.1098/rspa.1934.0109

Hardiman, S. C., Lin, P., Scaife, A. A., Dunstone, N. J., \& Ren, H.-L. (2017). The influence of dynamical variability on the observed Brewer-Dobson circulation trend. Geophysical Research Letters, 44(6), 2885-2892. https://doi.org/10.1002/ 2017GL072706

Harris, N. R. P., Hassler, B., Tummon, F., Bodeker, G. E., Hubert, D., Petropavlovskikh, I., Steinbrecht, W., Anderson, J., Bhartia, P. K., Boone, C.D., Bourassa, A., Davis, S. M., Degenstein, D., Delcloo A., Frith, S. M., Froidevaux, L., Godin-Beekmann, S., Jones, N., Kurylo, M. J., ... \& Zawodny, J. M. (2015). Past changes in the vertical distribution of ozone - Part 3: Analysis and interpretation of trends. Atmospheric Chemistry and Physics, 15, 9965-9982. https://doi:10. 5194/acp-15-9965-2015

Hartmann, D. L., Klein Tank, A. M. G., Rusticucci, M., Alexander, L. V., Brönnimann, S., Charabi, Y. A. R., Dentener, F. J., Dlugokencky, E. J., Easterling, D. R., Kaplan, A., Soden, B. J., Thorne, P. W., Wild, M., \& Zhai, P. (2013). Observations: Atmosphere and Surface. In T. F. Stocker, D. Qin, G.-K. Plattner, M. Tignor, S. K. Allen, J. Boschung, A. Nauels, Y. Xia, V. Bex \& P. M. Midgley (Eds.), Climate Change 2013: The Physical Science Basis. Contribution of Working Group I to the Fifth Assessment Report of the Intergovernmental Panel on Climate Change (pp.159-254). Cambridge: Cambridge University Press, United Kingdom and New York, NY, USA. https://www.ipcc.ch/report/ar5/wg1/

Hassler, B., Petropavlovskikh, I., Staehelin, J., August, T., Bhartia, P. K., Clerbaux, C., Degenstein, D., Mazière, M., Dinelli, B. M., Dudhia, A., Dufour, G., Frith, S. M., Froidevaux, L., Godin-Beekmann, S., Granville, J., Harris, N. R. P., Hoppel, K., Hubert, D., Kasai, Y., ... \& Zawodny, J. M. (2014). Past changes in the vertical distribution of ozone - Part 1: Measurement techniques, uncertainties and availability. Atmospheric Measurement Techniques, 7, 1395-1427, https://doi.org/ 10.5194/amt-7-1395-2014

Hood, L. L., \& Zaff, D. A. (1995). Lower stratospheric stationary waves and the longitude dependence of ozone trends in winter. Journal Geophysical Research, 100(D12), 2579125800. https://doi.org/10.1029/95JD01943 
Komhyr, W. D., \& Evans, R. D. (2008). Operations Handbook - Ozone Observations with a Dobson Spectrophotometer. GAW Report No. 183. World Meteorological Organization, Geneva, 2008. https://gml.noaa.gov/ozwv/dobson/GAW 183-Dobson-WEB.pdf

Laeng, A., Grabowski, U., von Clarmann, T., Stiller, G., Glatthor, N., Höpfner, M., Kellmann, S., Kiefer, M., Linden, A., Lossow, S., Sofieva, V., Petropavlovskikh, I., Hubert, D., Bathgate, T., Bernath, P., Boone, C. D., Clerbaux, C., Coheur, P., Damadeo, R., ... \& Zawodny, J. (2014). Validation of MIPAS IMK/IAA V5R_O3_224 ozone profiles. Atmospheric Measurement Techniques, 7, 3971-3987. https://doi.org/10.5194/ amt-7-3971-2014

Mateer, C. L., \& Dütsch, H. U. (1964). Uniform evaluation of Umkehr observations from the world ozone network: Part I, Proposed standard Umkehr evaluation technique. National Center for Atmospheric Research.

Mateer, C. L., \& Deluisi, J. J. (1992). A new Umkehr inversion algorithm. Journal of Atmospheric and Terrestrial Physics. 54(5), 537-556. doi:10.1016/0021-9169(92)90095-3

Milinevsky, G. P., Danylevsky, V. O., Grytsai, A. V., Evtushevsky, O. M., Kravchenko, V. O., Bovchaliuk, A. P., Bovchaliuk, V. P., Sosonkin, M. G., Goloub, Ph., Savitska, L. Y., Udodov, E. V., \& Voytenko, V. P. (2012). Recent developments of atmospheric research in Ukraine. Advances in astronomy andspacephysics, 2(2), 114-120.https://doi.org/10.1007/97890-481-9618-0_32

Myhre, G., Shindell, D., Bréon, F.-M., Collins, W., Fuglestvedt, J., Huang, J., Koch, D., Lamarque, J.-F., Lee, D., Mendoza, B., Nakajima, T., Robock, A., Stephens, G., Takemura, T., \& Zhang, H. (2013). Anthropogenic and Natural Radiative Forcing. In Climate Change 2013: The Physical Science Basis. Contribution of Working Group I to the Fifth Assessment Report of the Intergovernmental Panel on Climate Change (pp. 659-740). Cambridge: Cambridge University Press. https:// doi.org/10.1017/CBO9781107415324.018.

Petropavlovskikh, I., Bhartia, P. K., \& DeLuisi, J. (2005). New Umkehr ozone profile retrieval algorithm optimized for climatological studies. Geophysical Research Letters, 32(16). doi:10.1029/2005GL023323

Rex, M., Salawitch, R. J., von der Gathen, P., Harris, N. R. P., Chipperfield, M. P., \& Naujokat, B. (2004). Arctic ozone loss and climate change. Geophysical Research Letters, 31(4). L04116. https://doi.org/10.1029/2003GL018844

Staehelin, J., Kegel, R., \& Harris, N. R. P. (1998). Trend analysis of the homogenized total ozone series of Arosa (Switzerland), 1926-1996. Journal of Geophysical Research: Atmospheres, 103(D7), 8389-8399. https://doi.org/10.1029/97JD03650

Staehelin, J., Renaud, A., Bader, J., McPeters, R., Viatte, P., Hoegger, B., Bugnion, V., Giroud, M., \& Schill, H. (1998). Total ozone series at Arosa (Switzerland): Homogenization and data comparison. Journal of Geophysical Research: Atmospheres, 103(D5), 5827-5841. https://doi.org/10.1029/97JD02402

Steinbrecht, W., Froidevaux, L., Fuller, R., Wang, R., Anderson, J., Roth, C., Bourassa, A., Degenstein, D., Damadeo, R., Zawodny, J., Frith, S., McPeters, R., Bhartia, P., Wild, J., Long, C., Davis, S., Rosenlof, K., Sofieva, V., Walker, K., ... \& Tummon, F. (2017). An update on ozone profile trends for the period 2000 to 2016. Atmospheric Chemistry and Physics, 17, 10675-10690, https://doi.org/10.5194/acp-17-10675-2017

Stone, K., Tully, M. B., Rhodes, S. K. \& Schofield, R. (2015). A new Dobson Umkehr ozone profile retrieval method optimising information content and resolution. Atmospheric Measurement Techniques, 8, 1043-1053. https://doi.org/10.5194/ amt-8-1043-2015

WMO (World Meteorological Organization). (1998). The fifth biennial WMO consultation on Brewer ozone and UV spectrophotometer operation, calibration, and data reporting ( $\mathrm{Re}-$ port No 139). Geneva, Switzerland. https://library.wmo.int/ index.php?lvl=notice_display\&id=11071\#.Ya5DCNBBxZU

WMO (World Meteorological Organization). (2018). Scientific Assessment of Ozone Depletion: 2018. Global Ozone Research and Monitoring Project (Report No. 58). Geneva, Switzerland.

Received: 6 June 2021 Accepted: 9 December 2021

\section{Ю. Андрієнко ${ }^{1, *}$, Г. Міліневський ${ }^{1,2,3}$, В. Данилевський ${ }^{1}$}

${ }^{1}$ Київський національний університет імені Тараса Шевченка, м. Київ, 01601, Україна

2 Державна установа Національний антарктичний науковий центр

Міністерства освіти і науки України, м. Київ, 01601, Україна

3 Міжнародний центр науки майбутнього, коледж Фізики,

Університет Цзілінь, м. Чанчунь, 130012, Китай

* Автор для кореспонденції: andrienko.j@gmail.com

\section{Вертикальні профілі озону в атмосфері над районами Києва} та Антарктичного півострова за спостереженнями Umkehr

Анотація. Для аналізу вертикального розподілу озону над Києвом та над Антарктичним півостровом (станція «Академік Вернадський») використані спостереження методом Umkehr. Результати спостережень Umkehr були поперед- 
ньо оброблені з використанням програмного пакету UMK92, запропонованого Всесвітнім центром даних з озону та УФ-випромінювання (WOUDC). В результаті розрахунків отримано набір профілів вертикального розподілу озону для станції Kyiv-Goloseyev (2011-2021 pр.) та антарктичної станції Фарадей/Академік Вернадський (2005-2009 рр.). Аналіз профілів станції Kyiv-Goloseyev, отриманих за допомогою спектрофотометра Добсона D040, вказує на те, що максимум у розподілі озону в одиницях Добсона у шарі атмосфери товщиною 5 км (DU/layer) спостерігається в діапазоні 15-25 км висот із середнім значенням висоти $19.8 \pm 1.4$ км. Це відповідає шару максимального вмісту озону в стратосфері на середніх широтах. Максимальні значення вмісту озону протягом більшої частини років становлять 60-80 DU/layer. У деякі дні є випадки, коли ці величини є значно вищими. Характерною особливістю профілів є те, що менші значення максимумів вмісту озону відповідають літнім та осіннім місяцям, знаходяться в межах 60-75 DU/ layer. Зимовий та весняний профілі озону демонструють максимальні значення. Дослідження вертикального розподілу озону в Південному полярному регіоні також розглянуто у статті. Для аналізу вертикальних профілів озону в цій області використані спостереження Umkehr на антарктичній станції Фарадей/Академік Вернадський на спектрофотометрі Добсона D123 у 2005-2009 рр. Обробка даних та розрахунок вертикальних профілів озону проводилася відповідно до методології, розробленої для даних станції Kyiv-Goloseyev. Показано, що озонові профілі на антарктичній станції відрізняються великим діапазоном значень максимальної концентрації озону від 40 до 110 DU/layer. На відміну від даних середньоширотної станції Kyiv-Goloseyev, профілі антарктичної станції з меншими значеннями максимальної концентрації озону мають максимум на більшій висоті. Згідно з розрахунками, значення озону в максимумі розподілу озону різко змінюються від дати до дати в Антарктичному регіоні протягом періоду озонової діри.

Ключові слова: загальний вміст озону, клімат, озонова діра, сезонні коливання, спектрофотометр Добсона, стратосфера 